УДК : 327:323.28

\title{
ПОЛІТИЧНИЙ ТЕРОРИЗМ: ФОРМИ ПРОЯВУ
}

\section{Лікарчук Дар'я Сергіївна}

кандидат політичних наук,

Київський національний університет культури і мистецтв,

м. Київ,Україна

ORCID: 0000-0003-1603-7601

likarchukd@gmail.com
Надіслано:

15.10.2020

Рецензовано:

29.10 .2020

Прийнято:

06.11 .2020

Терористична політика одного індивіда може обернутися тероризмом для всього світу. Тероризм став однією з глобальних проблем сьогоднішнього дня. Він впливає на всі сфери існування сучасного суспільства, перш за все на безпеку, стійкість та функціонування політичних інститутів держави, стабільність багаторівневої системи соціально-політичних й міжнародних відносин. Вивчення політичного тероризму надзвичайно важливо для сучасної України, де проблеми насильства, поряд з економічними, соціальними, духовноідеологічними та ін., не дають розвиватися країні в напрямку зростання соціальної захищеності громадян, постійно «завертаючи» її на шлях щоденного виживання й протистояння, знижуючи безпеку нашої країни. Тому потрібно постійно уточнювати тенденції розвитку сучасного суспільного процесу, прогнозувати небезпеку та загрозу виникнення збройної політичної конфронтації. Це, в свою чергу, практично неможливо без постійного уточнення методологічних основ теорії політичного тероризму. Вирішення завдання вимагає глибокого теоретичного знання, проникнення у розуміння сутності й змісту тероризму. При цьому зростає роль політологічного аналізу. Руйнування стійко політичного середовища необхідно розглядати як стратегічну мету політичного тероризму. Спираючись на розбалансовану структуру соціуму, він прагне примусити суспільство функціонувати, розвиватися у заданому терористичними силами напрямку. Політичний тероризм перетворився у деструктивну силу, яка генерує соціальну, політичну нестабільність у міжнародному масштабі. Входження Європи у складний, суперечливий соціально-політичний процес, пов'язаний з кардинальною зміною векторів політичного розвитку, що склалися у XXI ст., безпосередньо відобразився на рівні, динаміці, спрямуванні розгортання політичного тероризму, а також на різноманітних формах його реалізації. Політичне життя Європи увібрало в себе цілий спектр політичного терору. 
Ключові слова: тероризм; політичний тероризм; міжнародний тероризм; EC;Global Terrorism Index 2020; терористична політика.

Likarchuk Daria, Ph.D. in Political Sciences, Kyiv National University of Culture and Arts, Kyiv, Ukraine

\section{Political Terrorism: Forms of Manifestation}

One individual's terrorist policy can turn into terrorism for the whole world. Terrorism has become one of the global problems of today. It affects all spheres of existence of modern society, especially the security, stability and functioning of political institutions of the state, the stability of a multilevel system of socio-political and international relations. The study of political terrorism is extremely important for modern Ukraine, where the problems of violence, along with economic, social, spiritual, ideological and others, do not allow the country to develop in the direction of increasing social security, constantly turning it to daily survival and confrontation, reducing the security of our country. Therefore, it is necessary to constantly clarify the trends in the development of the modern social process, to predict the dangers and threats of armed political confrontation, and to use extremist violence - terrorism. This, in turn, is almost impossible without constant clarification of the methodological foundations of the theory of political terrorism. Solving this problem requires deep theoretical knowledge, insight into the essence and content of terrorism. At the same time, the role of political science analysis is growing. The destruction of a stable political environment must be seen as a strategic goal of political terrorism. Based on the unbalanced structure of society, it seeks to force society to function, to develop in the direction set by terrorist forces. Political terrorism has become a destructive force that generates social, political instability internationally. Europe's entry into a complex, contradictory socio-political process associated with a radical change in the vectors of political development in the XXI century, directly reflected on the level, dynamics, direction of political terrorism, as well as - on various forms of its implementation. The political life of Europe has absorbed a whole spectrum of political terror.

Key words: terrorism; political terrorism; international terrorism; the EU; Global Terrorism Index 2020; terrorist policy.

Ликарчук Дарья Сергеевна, кандидат политических наук, Киевский национальный университет культуры и искусств, г. Киев, Украина

\section{Политический терроризм: формы проявления}

Террористическая политика одного индивида может обернуться терроризмом для всего мира. Терроризм стал одной из глобальных проблем современности. Он влияет на все сферы функционирования современного общества, прежде всего на безопасность, устойчивость и функционирование 
политических институтов государства, стабильность многоуровневой системы социально-политических и международных отношений. Изучение политического терроризма чрезвычайно важно для современной Украины, где проблемы насилия, наряду с экономическими, социальными, духовноидеологическими и другими, не дают развиваться стране в направлении роста социальной защищенности граждан, постоянно обращая на путь ежедневного выживания и противостояния, снижая безопасность нашей страны. Поэтому необходимо постоянное уточнение тенденций развития современного общественного процесса, прогнозирования опасностей и угроз возникновения вооруженной политической конфронтации. Это, в свою очередь, невозможно без постоянного уточнения методологических основ теории политического терроризма. Решение этой задачи требует глубокого теоретического знания, проникновения в понимание сущности и содержания терроризма. При этом возрастает роль именно политологического анализа. Разрушение устойчивой политической среды необходимо рассматривать как стратегическую цель политического терроризма. Опираясь на разбалансированную структуру социума, он стремится заставить общество работать, развиваться в заданном террористическими силами направлении. Политический терроризм превратился в деструктивную силу, которая генерирует социальную, политическую нестабильность в международном масштабе. Вхождение Европы в сложный, противоречивый социально-политический процесс, связанный с кардинальным изменением векторов политического развития, сложившихся в XXI в., непосредственно отразился на уровне, динамике, направлении развертывания политического терроризма, а также на различных формах его реализации.

Ключевые слова: терроризм; политический терроризм; международный терроризм; EC; Global TerrorismIndex 2020; террористическая политика.

\section{Вступ}

Нині ми все більше стикаємося з проявами різних форм тероризму. у повсякденному житті ми не вивільнені від різноманітних способів залякування. Насильство все частіше стає засобом міжособистісного спілкування на міжнародній арені. Первісні інстинкти виживання набувають нового соціального статусу, але від цього не стають менш жорстокими. Насильство в сучасному світі завуальовано новими законами й новою мораллю. Світ глобального підприємництва зробив людське життя потенційним засобом наживи. На перші шпальта суспільного життя все частіше виходять акти тероризму з політичними відтінками.

Ядерна зброя в руках терористичної групи чи цілої держави як засіб демонстрації свого військово-силового потенціалу особливо небезпечна. 
Можливість впливати на міжнародне політичне життя через демонстрацію сили зброї масового знищення, стає все більш доступним. Терористична політика одного індивіда може обернутися тероризмом для всього світу. Тероризм став однією з глобальних проблем сьогодення. Він впливає на всі сфери існування сучасного суспільства, перш за все на безпеку, стійкість та функціонування політичних інститутів держави, стабільність багаторівневої системи соціально-політичних й міжнародних відносин.

\section{Аналіз останніх досліджень і публікацій}

Теоретичний інтерес до проблематики політичного тероризму став найбільш стійким у XX ст., коли він перетворюється на постійного супутника політичного життя суспільства розвинених країн Європи. Значний внесок у розробку теоретичних проблем тероризму внесли такі вчені як П. Вілкінсон, Б. Крозье, Д. Карлтон, Ч. Добсон, Р. Пейн, Б. Джекінс, Д. Поуланд, Дж. Белл, П. Дженк, А. Шмідт, Дж. Поуст, Дж. Денікер, Р. Клаттербак, Я. Шрайбер, Р. Еріксон. Ними проаналізовано велику кількість матеріалів, що обумовлено високою активністю терористичних угрупувань у сучасному суспільстві; розкрито закономірності та визначено основні структурні елементи тероризму; запропоновано основні його форми.

\section{Виділення невирішених раніше частин загальної проблеми}

У світлі вищесказаного, наше дослідження орієнтоване на встановлення значимості проблеми політичного тероризму у світі та визначення нових форм його проявів.

\section{Формулювання цілей статті}

Виявити специфіку політичного тероризму та визначити форми його прояву.

\section{Виклад основного матеріалу дослідження}

Експерти з безпеки Кліффорд Сімонсен та Джеремі Спіндлав бачать у визначенні тероризму складні процеси, але які можна контролювати. Вони підходять до визначення поняття «тероризм» 3 точки зору поведінкового континууму й підкреслюють важливість звичаїв, звичок і законів для розвитку соціальних груп. Крім того, відзначають, що політичний тероризм - своєрідне явище суспільного життя, яке завдяки своїм шокуючим акціям - залякування, політичним гаслам, переслідуванням, убивству людей - не може не представляти небезпеки для функціонування і розвитку суспільства й в силу цього не привертати його пильної уваги (Simonsen, Spindlove, 2006, p. 214).

На думку Б. Лейзера, «...терористи створюють атмосферу відчаю або страху для того, щоб похитнути віру пересічних громадян у свій уряд». Разом $з$ тим він виокремлює причин виникнення тероризму (Global Terrorism Index 2020): 
- загострення протиріч у політичній, економічній, соціальній, ідеологічній, етнонаціональній та правовій сферах;

- небажання окремих осіб, політиків, груп і організацій користуватися прийнятою для більшості суспільства системою укладу життя й прагнення в отримані переваг шляхом насильства;

- використання терористичних методів окремими особами, організаціями для досягнення політичних, економічних й соціальних цілей.

А. Шмід та А. Джонгман провели дослідження й виявили, що тероризм, як правило, породжується (Schmid, Jongman, 1988, р. 113):

- наявністю соціальних, національних й релігійних проблем, що мають для даної соціальної, національної чи іншої групи значення і пов'язаних з їі самооцінкою, духовністю, фундаментальними цінностями, традиціями й звичаями;

- війною й військовими конфліктами, в рамках яких терористичні акти стають частиною військових дій;

- наявністю соціальних груп, що відрізняються від своїх ближніх й далеких сусідів високим рівнем матеріального добробуту та культури, а також в силу своєї політичної, економічної та військової могутності, що диктують свою волю іншим країнам й соціальним групам;

- існуванням таємних або напівтаємних товариств й організацій, зокрема релігійних, які наділяють себе магічними та месіанським здібностями, виробляють єдино правильне, на їхню думку, вчення порятунку людства або докорінного поліпшення його життя, створення ладу загального добра;

- невирішеністю важливих економічних й фінансових питань, у тому числі на законодавчому рівні.

Але знову ж таки, варто відзначити, що зміни останніх світових тенденцій, де сучасний тероризм неможливий без ЗМI, оскільки його основна мета - вплив на уряд через суспільство шляхом залякування останнього. Залякати суспільство неможливе без освітлення терористичних актів, які втратять сенс без публічності. Саме широкий розголос вчиненого акту, а не нанесення максимального матеріального збитку дозволяють домогтися максимального інформаційного шоку (Horgan, 2017).

Специфічна особливість політичного тероризму визначається здійсненням своєрідної «революції» у свідомості й перевороту в політичному мисленні суб'єктів політичної діяльності. Реалізація подібних якісних змін у свідомості тих, хто встав на шлях терору, реалізується через ідеологію політичного тероризму. Включення ï в реальний політичний процес створює необхідні умови для відтворення тероризму. Ідеологія політичного тероризму, перетворена терористичними силами на інструмент для формування у суб'єктів терористичної діяльності та політичної свідомості специфічної спрямованості, 
завдяки якій у них формується стійка ідейна мотивація, без якої політичний тероризм не можливий.

Вивчення політичного тероризму надзвичайно важливе для сучасної України, де проблеми насильства, поряд з економічними, соціальними, духовноідеологічними та іншими, не дають розвиватися країні в напрямку зростання соціальної захищеності громадян, постійно «завертаючи» iї на шлях щоденного виживання й протистояння, знижуючи безпеку нашої країни. Тому, потрібно постійно уточнювати тенденції розвитку сучасного суспільного процесу, прогнозувати небезпеку та загрозу виникнення збройної політичної конфронтації. Це, у свою чергу, практично неможливо без постійного уточнення методологічних основ теорії політичного тероризму. Вирішення цього завдання вимагає глибокого теоретичного знання, проникнення у розуміння сутності й змісту тероризму. При цьому зростає роль саме політологічного аналізу.

Нині політичний тероризм є особливим типом політичної боротьби деструктивних сил за владу й вплив на різні сфери соціуму. Тероризм перетворюється у постійно діючий, дестабілізуючий фактор суспільного розвитку.

Його небезпека визначається здатністю подолання сформованого геополітичного простору, в якості технології, незалежно від наявності бар'єрних географічних чинників (Bardin, 2004, p. 140).

Руйнування стійко політичного середовища необхідно розглядати як стратегічну мету політичного тероризму. Спираючись на розбалансовану структуру соціуму, він прагне примусити суспільство функціонувати, розвиватися у заданому терористичними силами напрямку. Політичний тероризм перетворився на деструктивну силу, яка генерує соціальну, політичну нестабільність у міжнародному масштабі.

Входження Європи у складний та суперечливий соціально-політичний процес, пов'язаний з кардинальною зміною векторів політичного розвитку, що склалися в XXI ст., безпосередньо відобразився на рівні, динаміці, спрямуванні й розгортанні політичного тероризму, а також на різноманітних формах його реалізації. Політичне життя Європи увібрало в себе цілий спектр політичного терору (Horgan, Taylor,2001, p. 18). Аналіз прояву, в тому числі його ідеологічних підстав, дозволяє розкрити стійкий характер функціонування політичного тероризму.

Нині проблеми політичного тероризму досліджуються в рамках політології, конфліктології, вайленсології, міжнародних відносин. У центрі уваги конфліктології знаходяться проблеми виникнення, типології, специфіки, врегулювання політичного конфлікту, вайленсологія займається дослідженням будь-яких насильницьких проявів (Likarchuk, 2015, p. 70). 
Насильницькі конфлікти мінливі, не схожі один на одного, тому важко вказати на єдині форми їх завершення або шукати будь-які універсальні способи ïх вирішення (Likarchuk, 2019, p. 45), проте прояви політичного тероризму мають власну специфіку та розглядати їх в рамках конфліктології, вайленсології або іншої політичної науки, як правило, виявляється недостатнім.

Головним завданням нового етапу дослідження повинно стати розкриття змісту політичного тероризму, особливостей його динаміки в умовах, що змінюють суспільно-політичне життя з метою вироблення найбільш ефективних способів запобігання й подолання.

Сучасні політичні реалії визначили актуальність й затребуваність теоретико-методологічного осмислення природи політичного тероризму як складного, різноспрямованого соціально-політичного явища. Дослідження цієї проблеми безпосередньо пов'язане 3 необхідністю визначення ресурсного потенціалу політичного тероризму, розглянутого в якості організаційних, матеріальних та релігійних підстав для його розгортання й відтворення,надання активного типу функціонування.

Як свідчить практика, спираючись на розгорнутий внутрішній ресурсний потенціал, сучасний політичний тероризм здатний надати суспільству якісно нового алгоритму розвитку - запустити механізм вкрай небезпечного військовополітичного явища, що визначається як терористична війна (McCormick, 2003, p.483). Тим самим, перевести соціум, його політичну систему у новий стан 3 високим рівнем драматичних і трагічних політичних перспектив як у локальному, регіональному, так й глобальному планах.

Аналізуючи сформований суперечливий досвід політичної історії, теорії та практики, назріла необхідність виробити розуміння тероризму як складного, системного утворення з багатосторонніми формами його вираження.

У світовій практиці суспільно-політичної науки політичний тероризм як глобальне, багатопланове явище став об’єктом всебічного самостійного аналізу й дослідження відносно недавно. Таке політичне насильство у всьому різноманітті його видів й форм не випадково є досить поширеним явищем у політиці протягом всієї історії людства, але у XXI ст. набуло найбільшого резонанасу. Саме у 2017 р. політичний тероризм набув нової форми прояву 22 травня відбувася вибух на арені Манчестера під час концерту, 3 червня у Лондоні одночасно було здійснено декілька терористичних актів на Лондонському мосту, ринку Борота в районі Воксхолл, 1 січня - в одному з нічних клубів турецького Стамбула. Саме з 2017 р. кількість терористичних атак з боку ультраправих удвічі зросла в США (3 серпня 2019 рокуторговельний центр «Walmart!) та на $43 \%$ - у Європі (Global Terrorism Index 2020). Усе це відображає відповідну політичну гру на міжнародній арені. 
Хоча Глобальний індекс тероризму (GTI) 2020 року показує, що загальна кількість смертей від тероризму знижується п'ятий рік поспіль із 33438 людей, убитих у 2014 р., до 13826 - у 2019 р.. GTI - щорічний звіт, опублікований Institute for Economics and Peace - окреслює тенденції даних про глобальні тенденції тероризму. На рис. 1 можемо бачити, що показники градації GTI 2020, Глобальний індекс тероризму (GTI) вказують на зменшення рівня впливу тероризму, що поширився в багатьох країнах (Global Terrorism Index 2020).
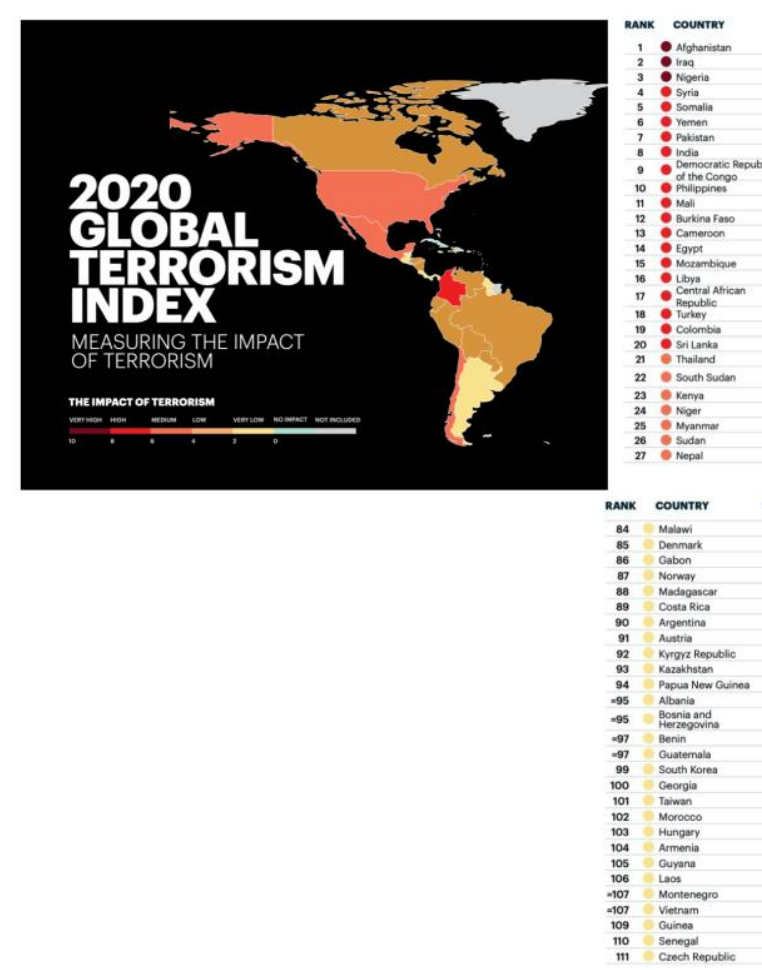
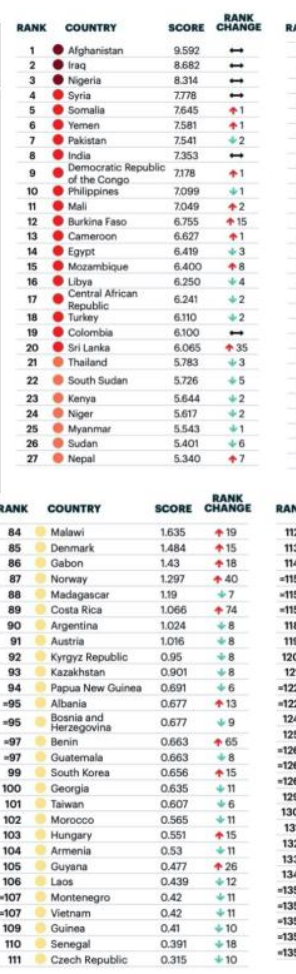
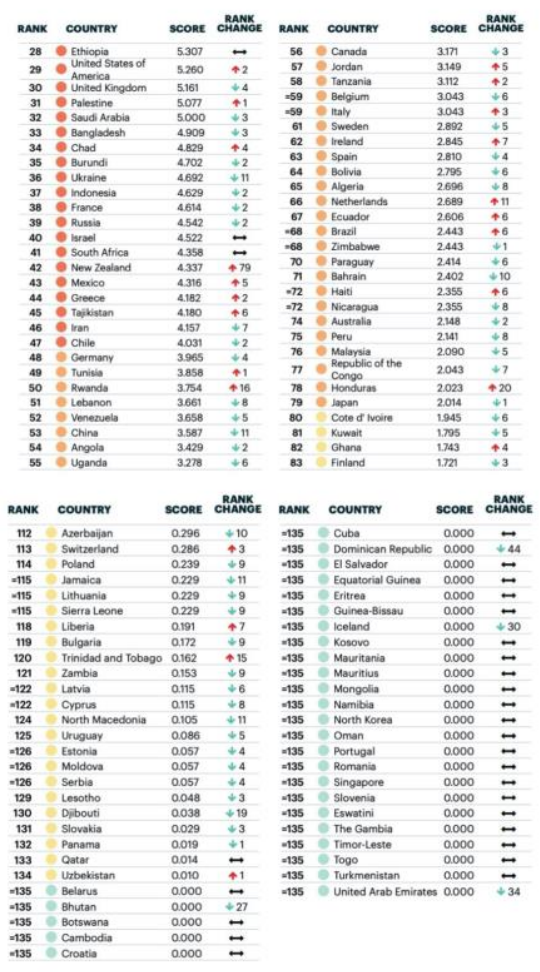

Рис. 1. GTI 2020

Незважаючи на загальне зниження кількості смертей від тероризму у десяти країнах, які найбільше постраждали від терористичних актів, глобальних змін не відбулося. Афганістан, Ірак та Нігерія утримували свої позиції відповідно першої, другої та третьої, що зазнали найбільшого впливу тероризму. Однак у рейтингу відбувся певний рух: Сомалі випередив Пакистан, п’яту країну, що зазнала найбільших наслідків, а Демократична Республіка Конго обійшла Філіппіни. Це вже вдруге, коли Сомалі потрапляє до п’яти країн, що мають найбільший вияв тероризму, це ми можемо бачити на рис. 2 .

Демократична Республіка Конго та Ємен були єдиними серед країн, що найбільше постраждали у 2018-2019 рр. від терористичних атак. Кожна 
Міжнародні відносини: теоретико-практичні аспекти

Випуск 6 (2020)

ISSN (print) 2616-745X; ISSN (online) 2616-7794

наступна країна 3 найбільш постраждалих покращила свій показник GTI за 2020 рік, причому найбільше поліпшення відбулося у Пакистані, за яким слідують Сирія та Нігерія.

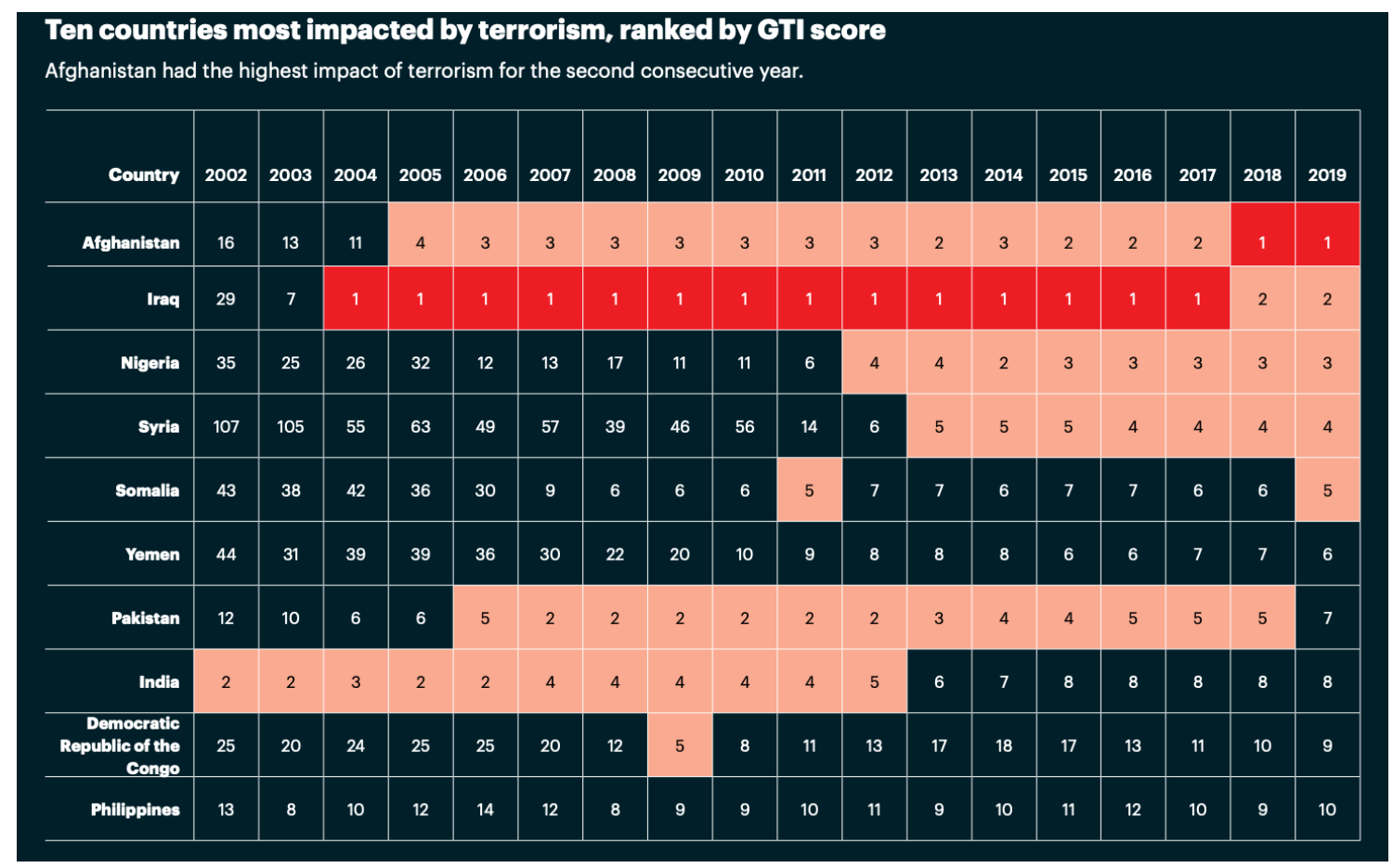

Рис. 2. ТОП 10 держав, які найбільше постраждали від тероризму, за рейтингом GTI 2020

Науковці вивчають ситуацію, що пов'язана з питаннями політичного тероризму, інтерес до якого не слабшає, це обумовлено комплексом причин, які доповнюють й підсилюють одна одну, роблячи більш вірогідним виникнення насильницьких політичних конфліктів. Найважливішими з них є різка соціальна диференціація й зрушення в сторону стратифікаційної системі, що радикально змінює статус груп відносно одна одної. Аналіз показує, що політичний тероризм здатний активно еволюціонувати, спираючись на розгорнуті ресурси. Цілеспрямоване їх застосування, забезпечує політичному тероризмові можливість активно відтворювати й реалізувати потенціал деструктивного насильства, перетворюючись на суттєвий фактор дестабілізуючого порядку регіонального та міжнародного рівня.

Але джерелом політичного тероризму є не лише зниження соціального статусу груп та індивідів, але й розрив між реальним й очікуваним поліпшенням їхнього соціального стану.

Аналіз основних форм владних відносин показує, що специфіка автократичної влади, прагнення абсолютного домінування владної еліти, 
роблять політичний тероризм поширеним явищем політичного життя. Деякі суб'єкти політики, відсторонені від процесу прийняття владних рішень, і не мають можливості захищати свої інтереси за допомогою легальних інститутів, беруть на озброєння терористичні форми політичної участі. Але й демократичні держави не застраховані від тероризму, оскільки асиметрія влади характерна для будь-якого типу панування (Франція).

На ймовірність вибору методів політичного тероризму в якості засобу захисту або розподілу влади впливає політична культура, яка може розглядати тероризм як допустимий спосіб політичної поведінки або, навпаки, засуджувати його (Primoratz, 2005).

Використання тероризму для досягнення політичних цілей також може бути обумовлено особливостями національної психології, в якій глибоке коріння мають нетерпимість та войовничість. Нарешті, індивідуальний вибір форми політичних дій залежить від специфіки особистості, яка може визначати схильність того чи іншого індивіда до насильства.

Проведений політологічний аналіз політичного тероризму як феномена суспільного життя дозволив виділити деякі методологічні особливості його вивчення: політичний тероризм виникає в результаті будь-якого конфлікту (Primoratz, 2005).

\section{Висновки}

Актуальність проблеми пізнання політичного тероризму обумовлена безперервним наростанням важких політичних, економічних та релігійних наслідків для світового суспільства, де тероризм виступає у вигляді специфічної форми прояву глибинних кризових тенденцій, що мають місце в різних сферах сучасного суспільства. Незважаючи на весь деструктивізм політичного тероризму, дотепер у науковому середовищі не вироблено однозначного розуміння цього явища. Результати дослідження динамічних характеристик політичного тероризму показують його багатовекторну структуру, яка знаходиться у безперервному процесі еволюції, що значною мірою ускладнює ідентифікацією поняття «політичного тероризму».

Ознаки політичного тероризму підтверджують його деструктивну, антисоціальну природу, здатну дестабілізувати суспільство, бути каталізатором загострення його соціально-політичних протиріч.

Проблеми політичного тероризму в сучасних суспільно-політичних умовах набувають все більшої гостроти. Він не обмежується лише засобами превентивного залякування, використовуючи найсучасніші види зброї масового ураження. Техніка й технологія здійснення терористичних актів розвивалися паралельно і в тісному зв'язку з розвитком військової техніки й часто навіть йшла на її випередження. 
В умовах мінливого суспільного життя виникають нові форми політичного тероризму, що використовують нові методи і засоби. Змінюється характер зародження тероризму, його прояви i, відповідно, запобігання й подолання.

Однак, практика показала, що можливості політичного тероризму не можна недооцінювати. У поєднанні 3 ідеологічною обробкою й широкомасштабним соціальним контролем він може на довгі роки паралізувати волю до опору, обумовити певну психологічну трансформацію свідомості значної частини суспільства, яка заважає їй зрозуміти, що вона підпорядковується владним наказам не за внутрішнім переконанням, а в результаті зовнішнього примусу.

\section{References:}

1. Bzhezinskii, Z. (1994). 'Vne kontrolya. Global'nyi besporyadok nakanune XXI veka' [Out of control. Global disorder on the eve of the 21st century]. SShA. Ekonomika. Politika. Ideologiya [The USA. Economics. Politics. Ideology], no. 4, pp. 3-10.

2. Bardin, 0. (2004). 'Predistoriia i henezys teroryzmu' [Prehistory and genesis of terrorism]. Liudyna i polityka [Human and politics], no. 2, pp. 130-144.

3. Likarchuk, D. (2019). 'Yevropeiskyi Soiuz ta Ukraina: perspektyvy ta problemy adaptatsii' [The European Union and Ukraine: perspectives and problems of adaptation]. Mizhnarodni vidnosyny: teoretyko-praktychni aspekty [International relations: theoretical and practical aspects], issue 3, pp.41-49. DOI: 10.31866/2616745x.3.2019.159101.

4. Likarchuk, N. V. (2015). 'Bazovi semiotychni modeli komunikatsii' [Basic semiotic models of communication]. Naukovyi chasopys Natsionalnoho pedahohichnoho universytetu imeni M. P. Drahomanova: Seriia 22 : 188 Politychni nauky ta metodyka vykladannia sotsialno-politychnykh dystsyplin [Scientific journal of the National Pedagogical Drahomanov University. Series 22: 188 Political Science and Methods of Teaching Socio-Political Disciplines], issue 16, pp. 69-74.

5. Global Terrorism Index 2020: Measuring the Impact of Terrorism. (2020). Institute for Economics \& Peace, [online]. Available at: https://www.economicsandpeace.org/?s=Global+Terrorism+Index.

6. Horgan, J., Taylor, M. (2001). 'The making of a terrorist'. Jane's Intelligence Review, Vol. 13, no. 12, pp. 16-18.

7. Horgan, J. G. (2017). 'Psychology of terrorism: Introduction to the special issue'. American Psychologist, Vol. 72, no. 3, pp. 199-204. DOI: http://dx.doi.org/10.1037/amp0000148/.

8. McCormick, G. H. (2003). 'Terrorist Decision Making'. Annual Review of Political Science, no. 6, pp. 473-507. 
9. Pape, R. A. (2003). 'The strategic logic of suicide terrorism'. American Political Science Review, issue 97(3), pp. 343-361.

10. Primoratz, I. (Ed.) (2005). State Terrorism and Counter Terrorism. Terrorism: The Philosophical Issues. New York: Palgrave Macmillan, pp. 113-127.

11. Simonsen, C. E., Spindlove, J. R. (2006). Terrorism today: the past, the players, the future. Upper Saddle River: Prentice Hall.

12. Schmid, A. P., Jongman, A. J. (1988). Political Terrorism: A new guide to actors, authors, concepts, databases, theories and literature. Amsterdam: North Holland Publishing Company.

13. Taylor, D. M., Louis, W. (2004). 'Terrorism and the quest for identity'. Understanding terrorism: Psychosocial roots, consequences, and interventions. Washington, DC: American Psychological Association, pp. 169-185.

(С) Лікарчук Д. С., 2020 